\title{
THE WORK OF JOSEPH AND ELEANOR EDWARDS, TWO LIVERPOOL ENTHUSIASTS*
}

In its educational work, the Liverpool Fabian Society constantly "situated" Liberalism; past reforms had done much, but contemporary Liberal aims were far too "wishy-washy" and diverse: "It is not benevolence, not charity, not a temporary dividing-up, that the world requires, but the transformation of industrial society from a system of profit into a system of co-operative production for use." Liverpool Fabians thus saw that a focus on the entire existing system, an attack on both root and branch, was essential to the distinction between radicalism and Socialism. ${ }^{1}$ It is primarily in the context of education towards an understanding of this kind of distinction that this article will consider the work of two Liverpool Fabian Socialists, Joseph and Eleanor Edwards, during the Liverpool phase of their activities, from 1891 to 1901.

If the Socialists were no more than a fringe and not always the most influential section of the labour movement, they were alone in engaging in an educational campaign of their own, which sought not merely to criticise, and offer alternatives to, existing educational (or social and economic) policy, but also to effect, ultimately, changes in society which would favour the implementation of a different educational emphasis. "Thus the

\footnotetext{
* Although Edwards's Labour Annual has long been used, and recognised, as a valuable source of political and social history for the late-Victorian-early-Edwardian period, there is no biographical account of its editor (1864-1946), nor of his first wife (née Keeling), an early contributor to the Clarion. The Harvester Press reprint of the Labour Annual and Reformers' Year Book (1895-1909) as part of The Labour Year Book 1895-1948, in the series British Political Sources: Political Party Year Books, ed. by John Spiers (Brighton, 1971), contains an introduction by David Marquand, but with only a brief note on Joseph and his wife (p. xxiii, note). I would like to thank my colleague Harold Entwistle, and Dr Martin Petter of McGill University, for comments on earlier drafts of this article.

1 Cf. John Edwards, Liberalism and Socialism: A Reply to Recent Speeches (Liverpool, 1906), p. 8; R. Harrison, review of W. Wolfe, From Radicalism to Socialism: Men and Ideas in the Formation of Fabian Socialist Doctrines, 1881-1889 (New Haven, 1975), in: English Historical Review, XCII (1977), p. 159.
} 
education of the people must precede and be the means of effecting their emancipation." 2 Morris and his Commonweal were referring to that educative process which, since the early nineteenth century, had become a fundamental aspect of the growth of working-class consciousness, an integral part of "the making of the English working class." As E. P. Thompson has argued, this "making" is to be found primarily in the response of the working class to economic exploitation, to the political economy of the middle class. The movement of labour away from Liberalism, like the clear distinction between the working and middle classes in the early nineteenth century, required in part an educational movement which was itself a component of the political struggle. For the early Socialists, much influenced by Morris, this educational movement entailed a steady process of "educating the people in the principles of Socialism", with a view to educating the labour movement away from its traditional association with the trade unions and co-operative societies towards a conception of a -singularly Socialist movement, as in the "root and branch" outlook of Liverpool Fabianism. ${ }^{3}$

While educating the labour movement was quite distinct from the business of representing the labour point of view on various boards and committees, the practical concern with formal policy and politics (as in school-board elections) could also be a function of Socialist consciousness and Socialist efforts at educating an entire movement. ${ }^{4}$ In Liverpool, a "somewhat difficult city", this was crucial; in a Tory stronghold characterised by the bitterness of its religious politics well into the twentieth century, the Liberal-radical tradition was relatively weak, and the "new unionist" upsurge of 1889-90 (which marked the rise of mass, unskilled trade unionism in the city) was mainly led by non-Socialists. Although this did effect the infiltration of a hitherto skilled, traditionally artisanal Trades

2 Commonweal, 4 May 1889; cf. Report of the Third Annual Conference of the Socialist League, 1887 , p. 6 , where Morris maintained that "the fight for education must be made part of the great struggle for a revolutionary change in the social conditions of life and the abolition of class distinction."

3 Report, ibid.; E. P. Thompson, The Making of the English Working Class (Harmondsworth, 1968), ch. 16; id., William Morris: Romantic to Revolutionary, revised ed. (London, 1977), Pt III, chs IV and VII; for the general educational implications of the rise of Socialism, see B. Simon, Education and the Labour Movement (London, 1965), ch. I; and for links between earlier radicalism and later Socialism, R. Harrison, Before the Socialists. Studies in Labour and Politics (London, 1965), ch. VI.

4 In Liverpool, this was especially true of Sam Reeves (1865-1930), a persistent schoolboard campaigner who believed that such candidates "must be both Trades Unionists and Socialists before they become a reliable factor in electioneering". See Labour Chronicle (hereafter LC), December 1894; also the sketch of Reeves by R. Bean in Dictionary of Labour Biography, ed. by J. Bellamy and J. Saville, I (1972), pp. 282-84. 
Council by an "advanced group" of Socialists (including the dockers' leader, James Sexton), the trade unions collectively represented in the Trades Council were wary of co-operation with the Independent Labour Party or Fabians. Thus, in the interests of a unified movement - vital for successful labour politics - the educating activity of such "advanced groups" was indispensable. ${ }^{5}$

It was with this in mind that, on a visit to Liverpool early in 1892 (before the formation of the ILP or Fabian Society in the city), Tom Mann insisted that trade unionists should endeavour to "find out the cause of labour difficulties" by means of "mental education - education in industrial economics - the education which is not picked up by the masses, either at school, in the workshop or anywhere else". ${ }^{6}$ This was "working-class education" as opposed to the provision of "education for the working class", in the sense that the former concept embodies a notion that working people "should be educated to meet the conditions of working-class life as they themselves saw it", as against the perceptions of those "from above". While this did not exclude the services of "traditional", or middle-class, intellectuals devoted to the cause of labour, it did underline the importance of educating the masses along the lines suggested by Tom Mann. Working-class education thus involved both a theoretical and a practical component, "education in industrial economics" being allied to the myriad activities of an increasingly defined working-class movement, with its clubs, societies, bands, lectures and branch business. In keeping with the nineteenth-century radical tradition of the autodidact, this continued to involve an education at the adult stage, although the spread of formal elementary education in the post-1870 era directed the attention of the labour movement increasingly towards the education of children.

While the focus on formal education (in board schools or technical classes) was mainly situated in the context of a drive for independent working-class politics, for many Socialists such a focus was aimed not merely at securing working-class access to varieties of formal education, but also at a working-class control of education, thus envisaging a move towards "coming to power" in the fullest sense. In practice, however, it was

${ }^{5}$ Labour Leader, 21 April 1894; R. Bean, "Aspects of 'New' Unionism in Liverpool 1889-189l", in: Building the Union. Studies on the Growth of the Workers' Movement: Merseyside, 1756-1967, ed. by H. R. Hikins (Liverpool, 1973), pp. 99-118; S. Maddock. "The Liverpool Trades Council and Politics, 1878-1918" (Liverpool University M.A. thesis, 1959), ch. II.

6 Liverpool Review, 20 February 1892.

7 M. Hodgen, Workers' Education in England and the United States (London, 1925), p. 262; cf. H. Silver, The Concept of Popular Education (London, 1965), ch. V. 
a question of securing the election of a number of bona-fide labour candidates to school boards or city-council committees, in the hope of influencing official policy in the interests of the working class (in the sphere of child welfare, for example); trade-unionist school-board candidates - like Henry Pearson or Charles Rouse in Liverpool -, while certainly representative of the labour viewpoint, were not the products of Socialist educating. ${ }^{8}$ There were nevertheless examples of Socialist emphases in curricular or pedagogical matters, as in the Socialist Sunday Schools, reflecting the tone of Socialist education in its broadest conception, in a concern, for example, for "the whole man" or for worthwhile citizenship. ${ }^{9}$ Some Socialists, like Joseph Edwards, looked to the elementary school itself as a prelude to the task of producing future Socialists, thus including it in the over-all work of educating the labour movement. ${ }^{10}$

Although not the only labour educators, locally or nationally, the Fabian Socialists were outstanding in this role, producing, and insisting upon, more than outright propaganda; and, by their tracts, lectures and scholarly investigations, placing the struggle for labour representation in the broad perspective of the education of a national movement. ${ }^{11}$ Reference to the Fabians is generally evocative of the London Fabian Society, primarily a London group, and relatively little is known of provincial Fabianism, especially as the majority of local societies were absorbed by the rapid and successful growth of the ILP in the North. However, the Liverpool Fabian Society was something of an exception to this, and stood alone among provincial societies in its remarkably continuous and active existence through to $1918 . .^{12}$ Partly stemming from its close association with the ILP (to a lesser degree, the Social Democratic Federation), partly from its predominantly working-class composition, it devoted itself more to "educating the masses" than to higher-level scientific investigations in the

${ }^{8}$ See Liverpool Daily Post, 15 November 1888, and Liverpool Review, 21 November 1891; cf. Simon, Education and the Labour Movement, op. cit., pp. 121-22.

${ }^{9}$ Cf. R. Barker, "The Labour Party and Education for Socialism", in: International Review of Social History, XIV (1969), p. 24.

10 The Liver, 13 January 1894 . For a view of the traditional elementary school curriculum as a desirable, perhaps necessary, component of subsequent radical education, see H. Entwistle, Antonio Gramsci: Conservative Schooling for Radical Politics (London, 1979); cf. E. P. Thompson, Education and Experience [Annual Mansbridge Lecture, No 5] (Leeds, 1968), pp. 18, 20.

11 A. M. McBriar, Fabian Socialism and English Politics, 1884-1918 (Cambridge, 1962), ch. VII; for a distinction between propaganda and education, see Hodgen, Workers' Education, op. cit., p. 270, citing Cole; cf. G. D. H. Cole, The World of Labour (London, 1913), pp. 16-17, 422 .

12 E. R. Pease, The History of the Fabian Society, 2nd ed. (London, 1925), pp. 102-03; cf. McBriar, Fabian Socialism, p. 167. 
style of the Webbs. ${ }^{13}$ While trade-unionist (including the Trades Council) and other Socialist bodies were simultaneously active in educational work in the 1890's, the Fabians appear to have been predominant, and to have provided the early stimulus to organisation and educational activity on the part of the ILP. In denouncing the Socialists, as late as 1897 , one press account associated them all with the Fabian Society. ${ }^{14}$

It was with this society that Joseph Edwards and Eleanor Keeling (whom Joseph married in 1895) were most closely identified during the 1890's. Neither of them was ever a great figure in the national labour movement, though, as editor of the Labour Annual and Reformers' Year Book from 1895 till 1908, Joseph acquired national recognition as "a notable Socialist pamphleteer", while it was once suggested that Eleanor be considered along with Enid Stacy, Katharine Conway, Margaret McMillan and Caroline Martyn as a possible woman member of the National Administrative Council of the ILP. ${ }^{15}$ Unlike the majority of Liverpool Socialists, including his wife, Joseph was new to Liverpool in 1891, although he was by then well acquainted with both Socialism and its peculiar setting in a great seaport. He was born of "village people of the labouring class" in Burton-on-Trent in 1864, and, following a five-year apprenticeship as a pupil-teacher in his home town, he began to develop a keen interest in local affairs, and in securing a wider experience of life. A position in HM Customs and Excise first took him to the Gravesend Boarding Station, where excessively long shifts and a severely disciplined regime led him to ask the "whys and wherefors", and to devote what time he could find to a study of the labour question. ${ }^{16}$ His work for the labour movement, subsequently, was a spare-time activity, for he continued to work as a Customs official during his Liverpool years and, quite probably, beyond. In this way, the route he took to Socialism, and his Socialist career, were familiar to many would-be Socialists, and Socialists, of his generation: a

13 See Shafts, 15 December 1893; Labour Leader, 13 October 1894; Porcupine, 11 December 1897; also Liverpool Fabian Society, First Annual Report, 1892-93 (unpaginated), British Library of Political and Economic Science (BLPES), Coll. Misc. 375/3.

14 Specifically, with "John Edwards and his Fabian host"; see Porcupine, 17 April 1897. John Edwards, who was of no relation to Joseph, was the Fabian president, and intellectual leader of the local labour movement until his virtual disappearance from public life after 1918; see Liverpool Daily Post and Mercury, 15 February 1922, and the biographical sketch by G. Fidler in Dictionary of Labour Biography, VI, forthcoming.

${ }_{15}$ Fred Greasley (ILP) to Eleanor Keeling, 7 April 1895, Joseph Edwards Papers. Liverpool Record Office, Acc. 2427; for Joseph, see the obituary notice in the Labour Party Annual Report, 1947, p. 31.

16 Shafts, 15 December 1893. Joseph lived until 1946, and had remarried by then. See obituary notice, ibid. 
practical experience of the conditions of industrial labour, and self-education in the theoretical framework of Socialism.

Familiar also, was the great influence of Henry George's theories of economic, especially land, reform on Joseph's chosen career, an influence which continued to manifest itself in his later writings, including his editing of the Land Reformers' Year Book in 1909. Joseph himself refers to the great impact of George on his career, and, in fact, it seems he had met and heard the American reformer; the Liverpool Fabian president, John Edwards, was similarly influenced by George's reading of Poverty and Progress, in 1882, and Liverpool Fabianism itself showed something of the Georgian emphasis. However, it is worth noting that this attachment would seem to confirm the view that George's influence on Fabianism - albeit, here, of the provincial sort - was more in his capacity as effective agitator and propagandist than in the realm of social and economic theory, the Georgian version of which Joseph (and John Edwards) went considerably beyond. ${ }^{17}$ Joseph certainly took every opportunity to recommend Poverty and Progress and Social Problems to his Socialist reading unions, and many of the topics included in his Labour Annual suggest that it was indeed Henry George who provided him with "the bridge between Radicalism and Socialism". ${ }^{18}$ Joseph's experience of the conditions of dockside labour in London, and then briefly in Londonderry, brought him especially to understand and sympathise with the casual dock worker, a disposition well suited to a Liverpool Socialist. It was with details of the London Dock Strike of 1889, and of his discussions with J. Havelock Wilson in Londonderry, freshly in his mind that Joseph was transferred to the Liverpool Custom House in 1891, at a time of widespread unemployment and discontent on the waterfront, and of active Socialist educating on the part of the Liverpool Socialist Society. ${ }^{19}$

It was probably through the Fabian Society, which quickly absorbed the Socialist Society, that Joseph met Eleanor Keeling, sometime in 1893. Little is known of Eleanor's life, other than her work as one of the most

17 Joseph Edwards, Economics of Freedom: adjustments necessary to secure to the Belgian people equitable social conditions (London, 1917); id., Land and Real Tariff Reform, being the Land Reformers' Handbook for 1909 (London, 1909); cf. John Edwards, Socialism and the Art of Living (Liverpool, 1913); McBriar, Fabian Socialism, p. 29; Shafts, 15 December 1893.

18 See E. J. Hobsbawm, "The Fabians Reconsidered", in Labouring Men. Studies in the History of Labour, 2nd ed. (London, 1968), p. 253.

19 Shafts, 15 December 1893; W. Hamling, A Short History of the Liverpool Trades Council (Liverpool, 1948), p. 27; for the Socialist Society (of which Reeves was secretary), see Porcupine, 12 December 1891; Fabian News, December; First Annual Report. 1892-93. 
active Liverpool Fabians of the 1890's. She was one of the young "new women" of the period, well-educated and bringing a great sense of purpose and leadership to the many facets of early Socialism; her enthusiasm, of a pronounced ethical sort, well matched Joseph's. ${ }^{20}$ She appears to have come from a middle- or lower-middle-class background (originally residing in a "comfortable" part of Wavertree, near Greenbank Park), and following studies in science, became an elementary-school teacher. In her spare time, she worked for the Fabian Society, first being involved in the formation of the Liverpool Cinderella Club, for the provision of periodical "Suppers and Entertainments to children of the slums"; this was "run by Socialists" and subsequently included "Fabian" in its title. ${ }^{21}$ At the same time, she was attached to the Society for Forming Women's Trade Unions (under Jeannie Mole, a prominent Liverpool Socialist also of middle-class background), which was absorbed by a branch of the Women's Industrial Council in February 1895, with Eleanor as secretary. Eleanor's task, here, was the basic and difficult one of educating largely ignorant, and for the most part intimidated, girls towards an appreciation of the benefits of trade-union organisation; an appreciation of the principles of Socialism might be the object of subsequent efforts. ${ }^{22}$

The progression to lecturing and related educational activities, from 1894 , was therefore probably a logical one. After inaugurating the women's column in the Clarion during the early part of 1895 (a column devoted to the informal education of potential "new women", and continued by Julia Dawson) Eleanor worked full-time for the labour movement, from January 1896. She lectured on such topics as "The New Faith", "The Heathen at

${ }^{20}$ Cf. H. Pelling, The Origins of the Labour Party, 2nd ed. (Oxford, 1965), p. 155, and S. Pierson, Marxism and the Origins of British Socialism (Ithaca, 1973), ch. 6. Her address to the Fabian Society in January 1894 (given also to the Birkenhead Fabian Society the following month) presented Socialism from "an ideal and ethical standpoint"; see Birkenhead News, 24 February, and Liverpool Fabian Society, Circular No 10, January, BLPES.

21 The first mention of Eleanor appears to be one in connection with the Fabian Cinderella Club, in Circular No 8, November 1893, when she was 22; see also the handbill outlining the objects of the club (n.d. [1894?]). BLPES; for a reference to her school teaching, see for example Mollie Keeling to Eleanor Keeling, 23 December 1895; Margaret Shurmer Sibthorpe to Eleanor Keeling, 17 January 1896, Joseph Edwards Papers.

22 Eleanor Keeling to workers in Lodge Lane Rope [works], 18 March 1896, Joseph Edwards Papers; for her work in the Industrial Council, see LC, January 1896; Porcupine, February 1893 and September 1894; The Women's Industrial News, April 1896. On Jeannie Mole, see Labour Annual, 1895, p. 180, and an article by Joseph Edwards in LC. January 1896. The scope of Eleanor's activities does not appear to have suited her health, "her enthusiasm [...] being not always unlimited by the claims of her own health". Labour Prophet (hereafter LP), April 1896. 
Home" or "A New Scheme of Education", at Fabian, ILP or Labour Church groups on Merseyside as well as in other districts of Lancashire and Cheshire. Although detailed accounts of her lectures are scarce, it seems she was an effective speaker ("most succesful" according to the Birkenhead News), and might have had an appeal to working-class audiences akin to that of Katharine Conway or Caroline Martyn. ${ }^{23}$ In 1897, she began a family, but soon resumed her lecturing activities; she also assisted her husband in the preparation of the Labour Annual. In fact, both worked as a couple for most of the 1890 's, sharing a common enthusiasm for ethical Socialism, which was well seen in their pioneer work for the Labour Church (Joseph being one of the early contributors to Trevor's Labour Prophet), to which both had progressed from nonconformist backgrounds, and their zest for the early women's movement. ${ }^{24}$ The Liverpool phase of their work covers three main areas: active participation in a number of Socialist organisations, with a conscious effort at fostering a spirit of harmony and co-operation; the education of women and children; and the propagation of Socialist principles by means of lecturing, writing, and the "permeation" of established organisations or institutions (notably the radical nonconformist chapels and churches). Much of this work had a bearing also on the national movement, for the Women's Industrial Council, for example, was nationally organised, while Joseph's Labour Annual was a work whose scope was intended to be universal.

When Joseph and Eleanor first entered Liverpool Socialist circles, there was already a tradition of radical educational activity in the city, mainly deriving from the Owenite and Co-operative ventures of John Finch (1784-1857) and continued, from the 1860's, in a number of radical and temperance coffee houses. One of these, run by an old Chartist, Edmund Wallace Jones, became a meeting-place for Liverpool positivists in the 1870's, one of whom was the Liverpool correspondent for the Bee-Hive (later Industrial Review) from March 1876. The latter was especially active in urging a more assertive trade unionism (especially through the Trades Council), for which a source of non-union "counsel" might be beneficial: "in these days of conflict between capital and labour, working men want

23 It was remarked that "there is a wonderful sweetness in your presence": Mollie to Eleanor Keeling, 5 November 1895, Joseph Edwards Papers; see also Birkenhead News, 24 February 1894, and LC, September 1897 and November 1898. Her column in the Clarion ran from 9 February to 20 April 1895.

24 Their interest in women's emancipation was noted with great satisfaction by the editor of Shafts (Margaret Shurmer Sibthorpe), "though Socialists have not yet grasped the full bearings of this question": Shafts, February 1896; for the Labour Church commitment. see Labour Leader, 21 April and 21 July 1894: LP. July 1892 and May 1894. 
counsel and assistance from the more thoughtful of their class who may not come within the direct category of "representatives". ${ }^{25}$ It was in the coffee-house meetings, with their social gatherings, vocal and instrumental music, recitations and speeches, and in an admixture of temperance, radicalism, positivism and early anarchism, that Socialism crept into Liverpool radical circles. It appears that it was Sam Reeves who "introduced" Socialism to the "Drum", the successor to Edmund Jones's establishment, and initially "a sort of H.Q. for temperance and philosophical societies". Reeves soon had a following of a "considerable number of men wearing red ties [. . . ] at the Sunday meetings", cultivating a new language of class, aggressive and uncompromising: "They introduced many new words and phrases, and we heard how under the present system, the profit-monger plundered the proletariat, leaving him without any economic basis, so that his environment was hopeless." 26

In the 1880's, there was a great variety of Socialist clubs and organisations, including the Workers' Brotherhood, and branches of the Democratic Federation (SDF from 1884) and the Socialist League (in both of which Reeves was active), all reflecting the pronounced ethical, almost visionary, outlook of the older Liverpool Ruskin Society. The Workers' Brotherhood was instituted to "spread the desire for social righteousness", while, according to one Liverpool Socialist of the 1880's, many members of the Ruskin Society had "advanced to our position" and were "hesitating to join us only because they wish to make certain that our League is one of righteous men resolved to win by righteous methods". ${ }^{27}$ There was also the influence of visits from "educational" Socialists like Morris, Carpenter and Blatchford ("Nunquam" of the Clarion), who spoke well of their Liverpool audiences, and brought a stimulus, in particular, to the matter of educating the working class, and to the practical means of securing Socialistic ends through its independent political organisation. ${ }^{28}$

Although it is not certain whether Joseph joined the Liverpool Socialist Society on his arrival in Liverpool, he was one of the members of the first Executive Committee of the local Fabian Society (founded in June 1892, at

25 Industrial Review, 29 December 1877; for Jones and the coffee houses, see T. "Joff", Coffee House Babble (Liverpool, n.d. [1915?]), p. 8, and Harrison, Before the Socialists, op. cit., pp. 320-21; for Owenite activity, R. B. Rose, "John Finch, 1784-1857; a Liverpool Disciple of Robert Owen", in: Building the Union, op. cit., pp. 31-52.

26 “Joff", Coffee House Babble, p. 26.

27 Pierson, Marxism, op. cit., p. 36, citing Socialist League Correspondence and Papers No 3251/2, Internationaal Instituut voor Sociale Geschiedenis; LC, January 1896; Liverpool Review, 23 February 1891.

28 Blatchford thought "the cause of Socialism is progressing in Liverpool", Porcupine, 12 December 1891: Commonweal, April 1896. 
the same time as the first local ILP), which absorbed all the members - and possessions - of the Socialist Society. ${ }^{29}$ It continued the work of earlier organisations in the educational sphere (lectures, debates, pamphlet literature), and although there seems to have been a similarly active SDF in the city, Joseph and Eleanor were drawn more to the ethical Socialism of the Fabian Society and ILP than to the Marxist body. Joseph's work was soon associated with a "flourishing", a "very active" Fabian Society, whose aggressive stance brought praise from Edward Pease of the London Society (whose opinion of provincial Fabianism was scarcely a flattering one): Liverpool "is rapidly removing the disgrace which it had so long of being the largest town in which there was the least Socialist agitation of any in England [...]. Congratulations on your energetic propaganda." 30

At the end of 1893, Joseph presented a paper to the Fabian Society, published shortly after in a series of articles in The Liver (edited by a Socialist convert from coffee-house days, Scot Anderson), which sought to foster a comprehensive and organised view of the work of local Socialism, and a wide understanding of the mechanisms of local government and politics. ${ }^{31}$ To facilitate effective action, his "Fabian Opportunities" outlined the work of a number of Fabian sub-committees, responsible for the press, parliamentary affairs, the Board of Guardians and School Board, trade unions and churches, as well as for the entertainment and social life of members. Above all, it addressed itself to the major educational task of Fabians: the need to cultivate an appreciation of the virtue of unity among workers, in relation to independent labour politics. For, as a member of the Trades Council remarked, just after the formation of the Fabian Society, "Liverpool is a cosmopolite city and united action on the part of the working classes is not easily secured." 32 Joseph praised the close cooperation of Fabians with the ILP and the SDF, a co-operation which appears to have characterised this phase of Liverpool Socialism, although relations with the SDF were not always easy, with disagreement on the class war and other issues. ${ }^{33}$ It was with the ILP that Fabians were most

29 With Joseph, were John Edwards, Reeves, Mole, Edward Kaney, George Nelson and Joseph Goodman (SDF); Sexton and Bob Manson ("Manzona" of the Chronicle) had joined by 1893. See Circular No 1, December 1892, and First Annual Report.

30 Pease to Joseph Edwards, 28 February 1893, Joseph Edwards Papers; for the SDF, see The Liver, 9 December 1893: "the S.D.F. in this city is a very active organisation."

31 "Fabian Opportunities", in: The Liver, 2 December 1893 - 20 January 1894. It also suggests the existence of some first-class minds among Liverpool Fabians. Pease's bias towards "university men" perhaps being unfair, see ibid., 9 December.

32 Porcupine, 24 September 1892.

33 Justice, 19 July 1902, but cf. 8 January 1898 , where the Fabian president praised the "uncalculating devotion to principle of the S.D.F." 
closely associated, and, indeed, Joseph and other Fabians (including John Edwards, James Sexton, John Morrissey and Bob Manson) were themselves instrumental in forming the first ILP in the city in June $1892 .^{34}$ In this respect, an overlapping of personalities must be taken into account in any explanation of the relative success, among provincial societies, of the Liverpool Fabian Society, as also, in part, its subsequent disapproval of London policy. ${ }^{35}$

By 1894, the growth of the ILP led to the formation of a Federal Council, co-ordinating the work of the seven branches in the city, and its educational activity (largely directed by Sam Hales, lecture secretary of the Federal Council) closely resembled that of the Fabians. In fact, its "elocution class", devoted to a study of political economy, Socialistic facts and Shakespeare's plays, followed Joseph Edwards's Fabian lessons of 1893 in its focus on the practical struggle as an expression of the theoretical training: Hales's classes were heralded as "a rare opportunity for the Socialist M.P.'s of the future". ${ }^{36}$ Activities in the ILP Labour Club in Phythian Street were frequently a joint Fabian-ILP undertaking, while Hales became a joint-editor, with John Edwards, of the Fabian-inspired Labour Chronicle in $1895 .^{37}$

While Liverpool Fabians were to disagree with London over election tactics, there is also evidence that the local ILP was critical of the NAC position respecting fusion with the SDF; it is quite clear that, unlike the London variety, Liverpool "progressivism" was never the Fabian ideal, in the entire range of urban social reform, including school-board policy in the 1890's and housing schemes for the working class in the early twentieth century. ${ }^{38}$ If leading Liverpool Fabians like Joseph or John Edwards remained enamoured of much of the earlier Georgian preoccupation with the land question, they had certainly moved beyond the appeal to the

34 J. Sexton, Sir James Sexton, Agitator (London, 1936), p. 150; Labour Leader, 21 July 1894; and Liverpool Daily Post, 30 December 1930, where Morrissey recalled that he and Sexton had joined an ILP which advocated "independence and the full Socialist Programme", before the formation of the national body.

35 See, for example, the publication of a statement on "Fabian Election Tactics", for the 1896 International Socialist Congress, which favoured co-operation with the SDF and ILP, in opposition to London Fabians, in Report on Fabian Policy, 1896, BLPES; cf. P. Poirier, The Advent of the British Labour Party (New York, 1958), p. 35, note.

${ }^{36}$ LC, October 1894: ibid., January-February 1895, for Hales's articles.

37 LC, October 1894.

38 Reeves spoke of "so-called Progressives" on the school board, and of a "conspiracy" against the poor; see LC, September 1898; for the Liverpool Housing Association (led by John Edwards) see Fabian News, December 1901. ILP, NAC minutes, 12 November 1898, BLPES, for a request from the Everton branch ILP for a re-opening of negotiations with the SDF. 
common interest of capital and labour that George had preached in his Liverpool visit of November 1888. And if, among the London Fabians, Webb, Pease and Headlam were anxious to keep the "wilder" Socialists quiet, and to prepare George for a stormy reception in 1889 , it was scarcely the sentiment of Liverpool Fabians subsequently, as it continued to be for Webb or Pease, that "it would be fatal to arouse the antagonism between the Radical and Socialist parties". ${ }^{39}$ At the first general conference of the ILP in Bradford in 1893, the two Liverpool representatives (Utley and Sexton, who were both Fabians) opposed the London Fabian attitude towards federation with the ILP, while at the second annual conference in Manchester the following year a letter was read out from the Liverpool Trades Council, wishing the conference success in forming "a party of the people outside of the two great political parties, who, from the elements constituting them, must of necessity be inimical to the interests of the working community". ${ }^{40}$ By this time - early February 1894 - Joseph Edwards's "Fabian Opportunities" could catch the mood, and the reality, of a Socialist upsurge; Socialist infiltration of the Trades Council, largely by Fabians and ILP'ers, reinforced the movement away from Lib-Lab politics.

The plan of attack outlined in "Fabian Opportunities" elaborated on the work of numerous sub-committees which had already been traced in the Fabian Society's first Circular, advocating the "careful watching and criticizing of all local governing bodies", but Joseph's concern was to invigorate a somewhat routine Fabian task by a sense of purpose and devotion. Thus, Socialists must "turn their back upon the feast" and make agitation their "raison d'être". ${ }^{41}$ Despite its practical note, the tone of Joseph's paper was unmistakably idealistic, as the Liver noted: "the paper was exceedingly well written, and read like a prose poem or a grand dream [...] but the dream of an enthusiast." It was an emphasis commonly encountered among Socialists of the Labour Church, or "new women" leaders like Caroline Martyn (frequently active in Liverpool), or Eleanor Keeling herself. ${ }^{42}$ Equally important to the effective organisation of

39 Sidney Webb to Henry George, 8 March 1889 (Webb's underlining). Henry George Letters, microfilm of English correspondence, BLPES; see Wolfe, From Radicalism to Socialism, op. cit., pp. $86 \mathrm{ff}$., for George as an orthodox economist whose writings led later English readers on to a serious criticism of the economic system. George's Liverpool speech was under the auspices of the Liverpool Financial Reform Association, which presented it as a lesson on the expediency of Liberal commitment for the working class; see "Henry George in London and Liverpool, December 1888". pp. 29. 31, BLPES.

${ }^{40}$ ILP. Annual Conference Report, 1894, p. 8; ibid., 1893, pp. 6-7, 14

41 The Liver, 9 December 1893; Circular No 1.

42 The Liver, 2 December 1893; LC, August 1895. 
Socialist agitation was the stimulus given to the spread of a whole range of social and recreative activities, which came to embrace much of the Clarion emphasis: clarionettes, Clarion Cycling Club, and regular rambles, concerts and other entertainments. In conjunction with the business of electioneering, such activities formed the basis of a distinctive Socialist educational milieu, resting on interests fundamentally different from those of other informal educational milieux. This milieu was an integral part of what Stephen Yeo has characterised and distinguished as a clear phase or epoch of Socialism, "the religion of Socialism".43 "Integral parts of Socialist life" (Merrie England, News from Nowhere or, indeed, the Liverpool Labour Chronicle) were also representative of an alternative kind of morality, a direct criticism of the morality of the capitalist educational system, as it was perceived by certain Socialists. ${ }^{44}$

Joseph's interest in the education of children, and in the "Woman Question", was much influenced by (and possibly largely derived from) his relationship with Eleanor Keeling, whose Socialist work and emphasis occurred mainly in this context. Educating children for Socialism, and a focus on the interests of women, were outside the mainstream emphases of the labour movement in the period, even among Socialists. On the first of these, there was much disagreement, and, in keeping with Marxist teaching, the priority was with adult education. Marx himself had opposed the teaching of political economy in elementary and even higher schools, this being "a kind of education which must rest with the adult, and must be left to the lecture room". ${ }^{45}$ Although, in the period, there were attempts to provide alternative forms of education for children, as in the experimental Escuela Moderna movement of Francisco Ferrer (which had disciples in Liverpool during the pre-1914 years), this was a fringe development, and most child and youth educational ventures were essentially envisaged as supplementary to the basic instruction of the elementary school, and, with this, preparatory to the all-important work of adult education in the service of the labour movement. ${ }^{46}$ This seems to have been true of Eleanor's work with women and children; but, in conjunction with lectures and writings, it was nevertheless an indication of the kind of pedagogical or curricular

${ }^{43}$ S. Yeo, "A New Life: The Religion of Socialism in Britain, 1883-1896", in: History Workshop, No 4 (1977), p. 30.

44 Ibid., p. 29; cf. R. T. Manson, Wayward Fancies (Liverpool, 1906), pp. 26, 28.

45 The Bee-Hive, 21 August 1869.

${ }^{46}$ Cf. Freedom, May 1909, on the Liverpool Communist School; the syndicalist Fred Bower failed "to understand why some of our comrades disagree with us in this method of propaganda". 
emphasis that Socialists like Eleanor or Joseph might have displayed on "coming to power".

Activities in connection with the Women's Industrial Council were, above all, a source of informal education (involving "recreation, instruction, and social intercourse"), and, associated with the Council, was a Women's Social Guild, with Eleanor as secretary. This would meet weekly in the early evening, when a "hostess" was "at home" to receive women workers. Its programme of instruction and amusement ("singing, reading, talking, dancing, games, gymnastics, etc.") ought to be seen in relation to Eleanor's view of the household and the "new woman's" place in it as wife and mother. Thus, making the home happy and comfortable was unquestionably a "worthy object", but the "new woman" - "the great She that is coming" - would obtain this object with less worry, strain or anxiety, and, in the process, look also to her own independent personal development. To such an end, Eleanor recommended schemes for collective cooking, and a widening of women's interests outside the home. ${ }^{47}$ The Guild was not a Socialist venture, but Eleanor exerted considerable influence over it, seeking to relieve working women and girls of much of the drudgery involved in keeping home. This was an indispensable prerequisite for the education of working women along Socialist lines, in the same way as the shorter working day for the education of labour generally. Eleanor also believed that the fruits of the combined mental and physical recreative activity of the Guild would be reaped, in some cases, by children: a corrective to the dullness, in this respect, of board-school education. Indeed, Eleanor was much implicated in the education of young Socialists, and began a recreative Socialist youth club in the ILP Club room, pervaded by the kind of social-ethical ambiance that filled the pages of Clarion or Merrie England, and characterised the Socialist Sunday Schools. ${ }^{48}$

Drawing perhaps on their experience of elementary-school teaching, both Joseph and Eleanor attached considerable importance to the potential of the elementary school (when under Socialist direction) for laying "the foundations of the principles of Socialism", thereby lessening Socialist dependence on post-school informal education derived from participation in the labour movement, or on self-education (at least in so

47 See LC, February 1896; Clarion, 9 February, 2 and 30 March 1895.

48 Eleanor advertised her "Liverpool Young Merrie Englanders' Club" in LC, August 1895, and LP, September; an account of the Women's Industrial Council appeared in the Reformers' Year Book 1904, p. 101: "the organisation of women's and girls' clubs for social and educational purposes" included a study of economics and legislation affecting women's trades. 
far as the principles of Socialism were concerned). ${ }^{49}$ In fact, Eleanor made this one of the few "salient points" in a lecture on education, an outline of which appeared in the Labour Annual for 1898. Her "suitable lessons" in economics and social science were aimed at bringing children to recognise "the evils underlying our present industrial and social systems": in effect, a notion which entertained a direct transposition to the regular day school of what was put into practice in the first Liverpool Socialist Sunday School, under the auspices of the ILP. Here, teaching was to result in a child's being able "to realise the incompatibility of competition with brotherhood", and this was facilitated by a division of the children - nearly one hundred of them by April 1896 - into small groups for reading and discussion of stories "of a Socialistic nature". Whereas Labour Church Socialists like Eleanor were active in the school, it was led by an ILP'er (Robert Weare) and was not a Labour Church school; like other Socialist Sunday Schools of this sort, it clearly focused on action, on the education of youth for the practice of Socialism. ${ }^{50}$ Eleanor made some curricular suggestions (for use in Sunday Schools generally), with model lessons, using themes suitable for children of various age-groups, and related to Socialist principles; for example, "bees: all workers share honey"; "birds in the air: air free to all"; or more sophisticated concepts, like competition or the division of labour. ${ }^{51}$

Although Eleanor and the Sunday School shared an interest in Froebelian, child-centred education (which was reflected in the emphasis on effective communication and, to some extent, on the notion of play as work), there was a definite commitment to formal teaching, which clearly had to draw on the basic skills acquired in the ordinary elementary school. There was also a hint of the puritan's zeal for "industry": one address to the Socialist Sunday School, for instance, lauded the wisdom of ants in their "political economy matters", intolerant of "idleness". ${ }^{2}$ Similarly, the teaching of Merrie England.

It seems, then, that even the children of educated, honest, and virtuous parents need to be carefully trained and guarded to prevent them falling into idleness and vice. For if children would grow up good without watchfulness and cultivation, it would be mere folly and waste of time and

49 The Liver, 13 January 1894.

50 LP, January 1896; cf. F. Reid, "Socialist Sunday Schools in Britain, 1892-1939", in: International Review of Social History, XI (1966), p. 20. For Eleanor's educational views, see "A New Scheme of Education", in: Labour Annual, 1895, pp. 145-46; for the Sunday School, LC, February 1896 and January 1897.

51 "Outline Addresses for Children", in: LP, October 1894; Eleanor also made suggestions for the use of lantern illustrations.

52 LP, May 1896. 
means to trouble about teaching them. [...] in our colleges, in our Sunday Schools, in our home lessons [...] we find an acknowledgement of the fact that a child is what he is taught to be. ${ }^{53}$

An emphasis of this order also in part informs the Liverpool Fabian School Board Tract of 1897, which spoke (somewhat cautiously, perhaps, in view of the forthcoming November elections) of "courses in the rights and duties of citizenship" which Socialists would provide. ${ }^{54}$ Joseph actually felt that these, coupled with adequate welfare measures, would go so far as to embody a preparation for "the 'Merrie England' that is going to be", though he displayed a practical, and careful, detail with respect to present-day "permeative" tactics, including the influencing of school teachers by their Fabian colleagues, who should "endeavour to teach the teachers". ${ }^{55}$ Realistically, he sought to concentrate Fabian effort on securing some representation on the school board, with a view to effecting a reform of what were seen as the negative elements of current educational practice and theory (in Liverpool, overcrowding, insufficient board school accommodation in working-class districts, school fees and the teaching of religion, for example). For this, he urged a common effort among trade unionists, ILP'ers and "labour men" at school-board elections. ${ }^{56}$ Ideally, the education of children - or of would-be "new women" - for Socialism should begin in the schools; small-scale youth work, or the Women's Social Guild, were in the nature of necessary palliatives.

Eleanor's position, in particular, is illustrative of the persistent contemporary Socialist demand that education, in the schools and elsewhere, must go beyond mere "mental instruction" and seek to provide for the total well-being of children and youth. On the one hand, this included the health and welfare of children that so preoccupied the Fabian Cinderella Club; on the other, it proclaimed a sensitive and reverent approach to the development of "all the faculties of the children", which, with Eleanor, extended to "simple, straightforward teaching on the physiology of sex". ${ }^{57}$ The high personal ideal with which her educational thinking was imbued displays the similar aura of spirituality surrounding the subject with other women Socialists, many of whom could also claim a direct experience of

\footnotetext{
53 Robert Blatchford, Merrie England (London, 1895), p. 160 (my emphasis).

54 Practical School Board Reform [Liverpool Fabian Tracts, No 8] (1897).

55 The Liver, 13 January 1894.

56 Ibid.; for labour criticism of the school board, see for example LC, December 1897; Porcupine, 17 November 1900; Liverpool Trades Council minutes, 11 September 1894, Liverpool Record Office, 331 TRA.

57 Labour Annual, 1895, p. 146: in preparation for what she saw as a reverent and prudent exercise of "the most important faculty of procreation".
} 
elementary-school teaching. ${ }^{58}$ However, Joseph Edwards saw the initiative to lie chiefly with the workers, the rank and file, the most important task being "to educate them up to a due appreciation of the duties and responsibilities of their position": in essence, the "rights and duties" of the Fabian School Board Tract. It was for this reason that the work of the Fabian Society "must be mainly educational", and directed at the "education of the masses". 59 There was a clear assumption that, if much working-class education in the conditions of the 1890's had to function at the adult stage, and often remain quite basic, it had also to be life-long ("one must continue to extend and broaden one's education"), and an integral part of Socialism. Such was the rationale behind Joseph's open library of Socialism at his "Reform Cottage" in Wallasey, his Fabian reading unions and study groups - as "schools" for future Fabians - and, essentially, his Labour Annual, which will be discussed below.

One of the most successful educational campaigns of the Liverpool Fabian Society was launched by Joseph Edwards in April 1893, as an integral part of his educating for Socialism. As secretary of the Fabian Church subcommittee, he issued a circular letter to various Protestant ministers in and around the city, requesting them to preach labour sermons on the first Sunday in May. Originally, this brought replies from twenty-seven ministers, "several of them revealing a quite unexpected amount of sympathy with the Fabian basis and program"; it soon became a regular activity, with sermons reproduced in the organ of Liverpool's "Radical Pulpit", the Liverpool Pulpit. ${ }^{60}$ A renewal of the tradition, with Methodism in particular, of socially tuned sermons and congregational activity, later in the nineteenth century, could ally itself quite readily with the "enthusiasm" of many Socialists, even if the general tendency was for nonconformity to lose touch with its working-class congregations. ${ }^{61}$ At this time, Liverpool nonconformity covered a wide range of dissent, being particularly well

58 Ibid., p. 145: "mere externals should be used only to promote the higher life": cf. Clarion, 23 March 1895, and Katharine Conway in The Workman's Times, 22 July 1893, Caroline Martyn in LC, April 1895 (education "should help children to be beautiful men and women").

59 Annual Report, 1893-94; LP, July 1892; Shafts, 15 December 1893.

60 Liverpool Pulpit, May 1893; Fabian News, March, May and August 1893. It was still a regular feature in 1900, when the Fabian Society had some eighty active members, see LC and Trade Union Reporter, May 1900.

61 "Church Going in Liverpool", in: Daily Post, 24 October 1891; much of the nonconformist decline in church attendance was attributed to the considerable population drift to the outskirts (i.e. of the middle class); cf. Pelling, Origins of the Labour Party, op. cit., p. 130, and E. J. Hobsbawm, Primitive Rebels (New York, 1965), ch. VIII. 
represented by Unitarians, Baptists and Methodists (notably of Welsh origin); there was also a vigorous Broad Church ministry, whose awareness of the dimension of Roman Catholicism in the city tended to associate it more closely than usual with the more "respectable" dissent. ${ }^{62}$

Indeed, it was Unitarian and Baptist ministers, in alliance with the socially tuned variety of Anglicanism, who together constituted Liverpool's "Radical Pulpit" of the 1890's. Rev. Charles Aked, Baptist minister of Pembroke Chapel, Rev. Richard Armstrong, Unitarian minister of Hope Street Church, and Rev. Charles Stubbs, Anglican rector of Wavertree, all effectively Christian Socialists, founded the Liverpool Pulpit, early in 1892, to give "local force and focus to the sentiment of spiritual unity amid intellectual diversity". ${ }^{63}$ Their sermons immediately set out to pronounce the attitude of the "New Christianity" to the labour question. Thus, in a series on "lessons from the history of Labour", Stubbs insisted that "high civilisation is not the destined lot of the few, while the destined lot of the many is to support the few by unremitting joyless toil". ${ }^{64}$ Other sermons closely identified the new teaching as "the Economics of Christ in the Light of the Sermon on the Mount", or, simply, as "Capitalism and Christianity". The latter, a sermon by Armstrong, effectively highlighted Socialist interest in the Pulpit: "I rejoice that they [a band of earnest men] recognise in the Christian pulpit an engine for the education of public thought and the arousing of public conscience." 65 That there was at all a promotion of the Social Gospel enabled Socialists to use its influence, as well as its organ, to further their own campaign; that Liverpool Socialists chose to do so, undoubtedly made the pulpit, and its supporters, such a radical influence.

Although at this time Joseph and Eleanor had moved into Trevor's Labour Church, they clearly welcomed the demonstration of a possible rift between the interests of capital and labour, as suggested by Armstrong's "Capital and Christianity". ${ }^{66}$ The Fabian campaign, and its success,

62 Rev. H. D. Roberts, Hope Street Church and the Allied Noncontormity (Liverpool, 1909), pp. 455ff.: for Liverpool Methodism, see I. Sellers, "The Methodist Chapels and Preaching Places of Liverpool and District, 1750-1971" (1971), typescript in Liverpool Record Office.

${ }^{63}$ Liverpool Pulpit, February 1892, title page; cf. I. Sellers, "Salute to Pembroke" (1960), typescript in Liverpool Record Office, p. 18.

64 Pulpit, December 1892; ibid., February 1892.

65 Ibid., May 1893.

66 For example, "I am quite at a loss to understand why the majority who are not rich should be proud of the minority who are [...]. We talk of masters and of men; though God makes no man the master of his brother", Pulpit, May 1893. For the Edwardses and the Labour Church, see LP, July and September 1892, July 1893 and May 1894. Eleanor was appointed pioneer secretary in 1894, cf. Labour Leader, 21 July 1894. 
emanated in a large measure from the common ethical base of both the "religion of Socialism" and radical nonconformity; whether it was a question of Christianising Socialism or of "Socialising Christianism", the crucial element was that

when sanitation, and education. and science, and political reform, and socialistic legislation, and the organisation of labour, have all done their best and failed, as they all undoubtedly will fail unless something more is also added, then I trust that we shall all of us [. . . ] begin to find out what that something more is. ${ }^{67}$

What this meant - and it was a key point of contact between Socialism and religion - was that "the rescue of political economy made possible the rescue of religion", as outlined by Henry George. ${ }^{68}$ Joseph Edwards's "Gospel of Labour" (which appeared in the Pulpit) might well have been substituted for Armstrong's "Capital and Christianity".

The Gospel of the new conscience must be preached by a Church which will know what its members believe only by what they do - a Church which will insist that every question between men is a religious question, one of moral economy before it becomes one of social or political economy. ${ }^{69}$

And it is the glory of Ruskin [.. . ] that he has sounded the note of this higher and wider political economy, and raised its subject-matter from bullionstatistics [...] to the whole problem of the welfare of man in communities and nations. [...] When we rise to this wider outlook, we perceive [ . . ] that a political economy which ignores Christianity is in a plight still worse than a Christianity which ignores political economy. ${ }^{70}$

This was the aim of "true education": not readily distinguishable from Carpenter's "ideal of Honest Life", which was underlined, as the end of education, in John Edwards's Socialism and the Art of Living (published for the Liverpool Fabian Society). ${ }^{71}$

The Fabian Church campaign begun by Joseph Edwards owed much of its success to the Christian Socialism of Charles Aked, in the period before the late 1890's, with its clear commitment to the working man. It was under Aked that Pembroke Chapel began an almost uninterrupted period of involvement with Socialists, which earned it a reputation as "the hot-bed of

67 C. W. Stubbs, “The Workers' Comrade King", sermon of 7 May 1893, in: Pulpit, May 1893 (Stubbs's emphasis).

68 Yeo, "A New Life", loc. cit., p. 19; cf. S. Pierson, "John Trevor and the Labour Church Movement in England, 1891-1900", in: Church History, XXX (1960), p. 465.

69 J. Edwards, "The Gospel of Labour", in: Pulpit, June 1893.

70 R. A. Armstong, "Capital and Christianity", sermon of 7 May, ibid.

71 John Edwards, Socialism and the Art of Living, op. cit., p. 38. 
Merrie Englanders" in the mid 1890's. ${ }^{72}$ Aked confined his educating to the pulpit and press, but shared the view held by F. D. Maurice, Carpenter and other early University Extension lecturers, that education was a spiritual force capable of transforming society, and thus urged Socialists "to educate and evangelize the enslaved masses of the people", rather than attack "gentlemen with commercial instincts". But, unlike Carpenter and other Socialists, who ceased to be Christian, Aked ceased to be a Socialist by the late 1890's, when he drove out the clarionettes from Pembroke, and engaged in an anti-Blatchford (and an anti-Hyndman) campaign.$^{73} \mathrm{His}$ response to the Fabian labour-sermon campaign, however, was initially very encouraging, and his own sermon proclaimed that "there is nothing in the nature of a divine decree, absolute or unalterable, in the system which compels the many to remain poor only so that the few may become rich". ${ }^{74}$

If Liberal radicals, like James Samuelson or Professor Oliver Lodge, expressed views in the Pulpit, Socialists also seized an opportunity to educate an influential audience. In fact, Sexton started a debate on the merits of competition, after suggesting the impossibility of practising Christian principles in the conduct of capitalist business, a theme which Aked - the "political parson" - could hardly resist. ${ }^{75}$ It was the response to issues such as unemployment or poverty which enabled Socialists to preach in their turn; Joseph's "Gospel of Labour" sought to "realise the ethical principles underlying the protest of the labour movement", while John Edwards heralded the "Angel of Association" over the "Devil of Competition", and there were contributions also from Sam Reeves, Jeannie Mole, Joseph Goodman and James Sexton. Above all, the aim was to seek an understanding of the cause, and to the extent that this was

72 Clarion, 5 October 1895; Sellers, "Salute to Pembroke", p. 32 . Aked was seen to take a "formidable stand on the broad social platform"; see Liverpool Review, 14 November 1891, and, for a selection of early sermons at Pembroke, his Changing Creeds and Social Struggles (London, 1893).

${ }^{73}$ Sellers, "Salute to Pembroke", pp. 18, 25; cf. S. Rowbotham, "The Call to University Extension Teaching, 1873-1900", in: University of Birmingham Historical Journal, XII (1969-70), p. 57. Although Sellers describes Aked as "an eager Fabian", it would seem that his Fabian leanings were more to the London sort than to the anti-"progressive" Liverpool variety. His association with Liberals, notably during the 1893 municipal elections, brought considerable Socialist criticism, Reeves issuing an open warning that "Your present good reputation can only continue on condition that you come out from among them; by the company you keep shall you be known." See The Liver, 21 October 1893; cf. Sellers, "Nonconformist Attitudes in Later Nineteenth Century Liverpool", in: Transactions of the Historic Society of Lancashire and Cheshire, CXIV (1962), p. 221.

${ }^{74}$ C. F. Aked, "Gurth the Son of Beowulph", in Changing Creeds, op. cit., p. 184.

75 Pulpit, September-October 1894, for correspondence between Sexton and "A Liverpool Merchant". 
facilitated by an educational campaign in press and pulpit, as well as by Socialist participation in debate and discussion (as at Pembroke and other "nurseries of advanced thought"), it was a successful Fabian campaign. Its main weakness was that it was of necessity limited. It could scarcely hope to convert more than a handful of middle-class or professional onlookers, while working-class congregationers, or readers, were but a small minority of the masses, among whom, moreover, was a sizeable Roman Catholic (largely Irish) population, which was quite outside the Protestant sphere of influence. It was with such considerations in mind, perhaps, that Sexton who was himself a Catholic - generalised the work of education: "It is the duty of every just, God-fearing man "who desires the welfare of the working classes' to educate the ignorant and expose the exploiter to a full sense of his duty to his kind." 76

If Joseph Edwards's work as a Liverpool Fabian remains largely unknown, such is not the case with his Labour Annual, a work which seems to have arisen from his Fabian activities during 1893. Its very scope - it was to be a "Labor Whitaker of Facts, Figures, Parties, Papers, Societies, etc., with special articles on every phase of the Social Question" - bore witness to the multiplicity of Liverpool Fabian campaigns. Joseph first presented the idea publicly in his "Fabian Opportunities" paper, having previously discussed it with John Edwards, who thought: "This was a grand idea. I think much could be made of it." ${ }^{77}$ Apart from his wife's assistance, Joseph himself undertook the entire production of the Annual from 1895 till 1903 (in 1901, it became the Reformers' Year Book), from which time suitable joint-editors were found, first in Percy Alden, and then F. W. PethickLawrence, who largely directed the work until it ceased publication in 1909. Apart from "earning a living for himself and family" in HM Customs, Joseph combined the duties of "correspondent, canvasser, reporter and reviewer, [...] of editor, printer, publisher and bookseller", and it is not surprising that this occasioned frequent "overwork and illness" and a considerable personal sacrifice. ${ }^{78}$ The Annual was issued by the Manchester Labour Press ("Co-operative Printers, Publishers, and Bookbinders") and the London Clarion Company, and financed with great

${ }^{76}$ Ibid., March 1893, which also contains the other Socialist contributions.

77 John Edwards to Joseph Edwards, 12 December 1893, Joseph Edwards Papers; The Liver, 6 January 1894, where Joseph suggested the idea in relation to his advice on propagandist activities, including the "permeation of the press"; he was clearly optimistic about the future of Liverpool Fabianism, even jesting that "a branch of the Liverpool Fabian Society has been started in London!"

${ }^{78}$ See Labour Annual, 1898, editorial preface; Reformers' Year Book, 1901, p. 76. 
difficulty by Edwards himself, by advertising, donations and subscriptions. Joseph later associated his fourteen years' work on the Annual with "much labour and with heavy monetary loss", but it was a "Labour of Love".79 Financial uncertainty led him to seek support from "friends of reform movements" (such as George Cadbury), and thus to widen the scope of the Annual still further; this would seem to lie behind the change of title in 1901 , embracing the entire spectrum of reform. ${ }^{80}$

Joseph initially envisaged the Labour Annual as, potentially, "a tremendous weapon in the hands of the workers", and his own conception of it extended beyond a simple "Labor Whitaker". Others shared this conception, despite some Socialist criticism of the all-inclusive coverage of reform movements. Predictably, perhaps, the Free Labour Press even spoke of its incitement of "revolutionary" thinking. ${ }^{81}$ The motto with which the Annual was inscribed ("Each aiding each the higher truths to find") suggests the kind of conception Joseph had of the work. Taken from a poem in Woman Free, issued by the Women's Emancipation Union in 1893 , this embodied the kind of "educational" process which, as an ingredient of ethical Socialism, was central to all human relationships. It thus encompassed the relationship of man to man, or man to community, as well as the "sweeter and diviner relations of "man intelligent and woman free", which were the immediate concern of the poem. Elsewhere, Joseph made this more explicit by quoting directly from Social Problems to place the Annual in the context of the "work of education [...] the propagation of ideas", which was also integral to the practical struggle: "The great need of the majority of the people now is real education. Given enlightened ideas, a better appreciation of objects and unity of aims, and the battle is already half-won". 82

The Annual was clearly a "work of education", which sought to engender a union of the scattered Socialist bodies into what Joseph called a

79 Land Reformers' Handbook, 1909, p. 32: Labour Annual. 1898, editorial preface. Eleanor's income from lecturing was also used to help defray the expense of producing the Annual, see the notice ibid., 1900, p. 25.

${ }^{80}$ By 1897 , Joseph had to assume responsibility for $£ 120$ on the issues, which led to several appeals for help; see Labour Annual, 1897, p. 7: Porcupine, 9 October and 6 November 1897; LC, February 1900 and May 1901.

81 The Free Labour Press, February 1896, also declared that the Annual "assumes that a Labour Movement can only be associated with Socialism"; ibid., June 1896; for Joseph's conception, see his editorial prefaces to the 1895 and 1896 Annuals, and The Liver, 18 November 1893.

82 LP, August 1894; Fabian News, August 1902. The sentiment of the Annual's motto was reinforced by a quotation from Tennyson: "Ring out the nobler modes of life / With sweeter manners, purer laws”, editorial preface, 1895. 
"National Federation", a chief object of both the Annual and, in the local setting, of Liverpool Fabians. The latter's Labour Chronicle (begun in 1894, and outstanding among local labour papers of the time) attempted to foster a similar spirit of co-operation, carrying regular notes on the many facets of the movement. Like the Chronicle, however, the Labour Annual tended somewhat to underestimate the importance of the trade unions in the movement, whose real power was underlined, in the case of the Chronicle, when they assumed control of the paper in 1900, through the Trades Council; the Reformers' Year Book similarly redressed the balance from around 1903, through Pethick-Lawrence. ${ }^{83}$ In the quest for unity, Joseph shared a Socialist vision of the "One Socialist Party", which was to be the result of an educational process and which, itself, would greatly assist "by the educational effect of its organisation all those whose greatest desire is for unity" ${ }^{84}$ It was a theme that Joseph had developed from as early, at least, as 1892, when he had spoken of "an evolution [. . .] through organisation and education". Then, in May 1893, William Morris had addressed him in connection with the labour-sermon campaign: "These [the people] need education; they want to be shown what to demand, and how to do so. This is the task of us Socialists" ${ }^{85}$ Quite possibly, this was the germ of "Fabian Opportunities". However, the quest for Socialist or labour unity was perhaps weakened by the vast array of issues and movements documented in the Annual (which was itself a tribute to the Edwardses' own informed interests, from mainstream Socialist bodies to theosophy, vegetarianism, and foreign labour movements). Although Joseph gave prominence to Socialist interests, he was obliged to "solicit the help" of reformers, for financial reasons; moreover, he was not a professional editor, and had to learn through the experience of producing successive volumes. But a major criticism was persistently made: the immense sweep of topics invariably included a number of irrelevancies, even some contradictions, as far as education in the "true" interests of the labour movement was concerned (as in an advertisement for the Free Labour Press).

83 D. Marquand, introduction to The Labour Year Book 1895-1948. op. cit.. pp. xii-xiii; the editor of the Chronicle was well aware of this tendency, wishing "to get more Trade Unionism in", see John Edwards to John Shannon (Trades Council), 20 December 1896. Trades Council Correspondence, Liverpool Record Office, 331 TRA.

84 "One Socialist Party", in: LP, May 1896; other contributors included Keir Hardie and Tom Mann.

85 William Morris to Joseph Edwards, 5 May 1893, in LP, July 1893, cited by Thompson. William Morris, op. cit., p. 610. The J. Edwards referred to in Thompson's note was in fact Joseph, who read out Morris's letter at a Labour Church service on Labour Day; cf. "The Knights of Labor", in: LP, July 1892. 
In as much as these true interests were seen to lie with Socialism (as Morris urged, and as Liverpool Fabians taught), the united labour party could only be Socialist. ${ }^{86}$ Paradoxically, therefore, while seeking to establish a fundamental unity in the Socialist spectrum, the Labour Annual could also nurture the belief that such a union was not only to encompass avowedly Socialist organisations. It might be that this paradox was only "apparent", in the sense that most Socialists were themselves fashioned out of the Liberalism of their own mid- or late-Victorian society in which the appeal of Socialism was characterised, above all, by its catholicity. ${ }^{87}$ But it is clear, on the other hand, that the Socialism of Joseph Edwards (like that of John Edwards and other Liverpool Fabians) was distinct from "social" Liberalism, seeking a "final solution" of the labour problem through a "Party of the People" which would know neither liberal nor radical. ${ }^{88}$ Somewhat benignly, Edward Pease suggested that "the editor is [. . . too industrious and copious", but criticism of non-Socialist elements continued, and the SDF was slow to forward information to the "persistent" editor. ${ }^{89}$ The range of topics (which also included detailed lists of lecturers, Socialist literature and valuable biographical portraits) was more happily accommodated under the revised title of the Annual, but the Reformers' Year Book had much less of Joseph Edwards in it than of Pethick-Lawrence, who largely wrote the editorials after 1903.

Given the circumstances in which it was undertaken, it is surprising that the Annual was produced at all, let alone for over a decade, and it was a more detailed work than later Labour Party Yearbooks, for which it was the prototype. Whatever its shortcomings, it was deliberately produced as an educational tool in the interests of a united Socialist labour movement. Moreover, in the compilation and distribution of the volumes, Joseph exploited his links with various Socialist organisations (including the London Fabian Society, of which he and Eleanor were also members) placing local Socialist endeavour in a more national perspective. In this, he met one of Morris's most urgent desires: "Locally, I believe, there is much mutual work going on between the different bodies; but in order to gain

${ }^{86}$ Cf. Thompson, William Morris, pp. 610-11; for criticism, see for example LC. January 1896, and I.L.P. News, June 1901.

$87 \mathrm{Cf}$. Marquand, introduction, loc. cit.. pp. xiv-xv; for the catholicity of Socialist appeal, see Yeo, "A New Life", p. 30. Marquand's interpretation is also briefly criticised by Royden Harrison in a review of the Harvester Press reprints, in: Bulletin of the Society for the Study of Labour History, No 25 (1973), pp. 113-14.

88 "The Knights of Labor", loc. cit.,; cf. John Edwards, Liberalism and Socialism. op. cit.. p. 8, and Sam Reeves, "Socialism: what it is and what it is not", in: The Liver, 6 January 1894.

89 Fabian News. January 1897 and February 1900. 
considerable success, it ought to be more than local, it ought to be universal". ${ }^{90}$

In part a by-product of this publishing and editorial activity, in part the natural outcome of Fabian educational effort, the Edwardses' home, "Reform Cottage" (from 1896, in Wallasey, near Liverpool), became an extensive reference library of Socialism and social reform. Joseph also made it a lending library, a "Labour Clearing House", so that it might reach workers at large, in much the same way as he constantly recommended Progress and Poverty, a work well suited to the ordinary worker (who was no "scientific thinker"). As a "centre around which the most prominent workers are found to cluster", the Liverpool Fabian Society also produced simple, straight-forward literature of its own; but the choice of Oliver Lodge's "Competition versus Co-operation" as a Fabian Tract, for example, was especially apt in view of the component persuasions of Liverpool Socialism: "Dr. Lodge is as simple as 'Nunquam', as convincing as Lassalle, as practical as Gronlund, as sound as Marx."91 Joseph also engaged in the more scholarly investigatory work typical of London Fabianism, beginning research into the history of Liverpool's municipal institutions, and subsequently turning to a study of economic and land reform. By then, however, the Edwardses had left Liverpool, Joseph being transferred to Clydeside in June 1901; from early 1906, they had settled in London, where Joseph appears to have devoted himself to writing. ${ }^{92}$ A link between the "enthusiastic" epoch of Liverpool Socialism and the period of the early "Labour Party" in the City Council, therefore, was provided by other Fabians, notably John Edwards and Sam Reeves.

If a limitation on the work of these two enthusiasts was imposed by its necessarily "spare-time" nature, there was also the fact of a peculiarly difficult socio-political climate in Liverpool, where the sphere of workingclass politics was dominated, and complicated, by the presence not only of a largely conservative variety of Liberalism, but also of a powerful Workingmen's Conservative Association (of mainly Protestant Orangemen), and

90 "What is Our Present Business as Socialists?", in: LP, January 1894. For correspondence with Edward Pease, and notes of a trip to London on Annual business, in 1898, see the Joseph Edwards Papers: Joseph also established contacts abroad, sending copies of Liverpool Fabian Tract No 3 to the United States, LC, September 1895.

91 Labour Leader, 13 October 1894; Competition versus Co-operation [Liverpool Fabian Tracts, No 3] (1894); cf. Porcupine, 31 December 1892.

92 See Economics of Freedom, op. cit., and the Land Reformers' Handbook (of which there appears only to have been the 1909 issue). According to a notice in Justice, 13 January 1906. Joseph was also involved in collecting radical election literature. 
(to a lesser extent) of Catholic Irish Nationalists. ${ }^{93}$ In the face of such rivals, the labour movement could not hope to succeed without presenting a unified front; it was to secure the unity of a Socialist labour movement that the work of Joseph and Eleanor Edwards was devoted to education for Socialism. Their activities afford some insight into the close interrelatedness of many early Socialist spheres of agitation, especially at the local level. Irrespective of any overlapping of personalities from one sect to another (a common feature of the nineteenth-century labour movement), these could form a basis for effective co-operation among independent Socialist organisations, as in the common concern of Liverpool Fabians and ILP'ers (sometimes working with the SDF) with unemployment or with school-board elections. ${ }^{94}$

There were never any notable successes during the Edwardses' Liverpool period, in terms of labour representation (even on the school board, where Socialists elsewhere knew a considerable success), and were it not for his Labour Annual Joseph's Socialist work might easily have been forgotten, along with his wife's. Their educating, accompanied by an intense optimism and enthusiasm, identified them with the spirit of early Fabian Socialism in general, and the ethical persuasion of early Liverpool Fabianism in particular. Moreover, despite a close association with the ILP, Liverpool Fabians like Joseph and Eleanor continued to be active as Fabians as much as their London counterparts. ${ }^{95}$ Above all, they grasped the significance of Morris's "new understanding of the dual role of practical and theoretical struggle": "This education by political and corporate action must [.. .] be supplemented by instilling into the minds of the people a knowledge of the aims of socialism, and a longing to bring about the complete change which will supplant civilization by communism". ${ }^{96}$ But, although Socialists were able to influence discussion and policy, as in the Trades Council, and thus form an important strain in the voice of labour,

93 See for example Liverpool Review, 9 January 1897; B. D. White, A History of the Corporation of Liverpool, 1835-1914 (Liverpool 1951), esp. pp. 101ff.; S. Salvidge, Salvidge of Liverpool, 1890-1928 (London, 1934), for the Workingmen's Conservative Association, of which Archibald Salvidge was leader; L. W. Brady, "T. P. O'Connor and Liverpool Politics, 1880-1929" (Liverpool University Ph.D. thesis, 1968), esp. chs IV and V. See also P. Clarke, Lancashire and the New Liberalism (London. 1971). pp. 45ff.

94 See LC, July 1896; ibid., November 1894 and October 1900 for co-operation at school-board elections.

95 Cf. Margaret Cole, The Story of Fabian Socialism (London, 1961), p. 32, and McBriar, Fabian Socialism, p. 166. In particular, John Edwards continued to lead study groups and to lecture as a Fabian in the period up till 1918.

${ }_{96}$ Thompson, William Morris, p. 614, citing Morris's lecture to the London Fabian Society in 1893, on Communism. 
the practical struggle did not only involve the Socialists in the labour movement. In this respect, much of the theory of Socialism, and of the idealism of Socialist enthusiasts, was not absorbed by the British labour movement as a whole. 